\title{
Pengaruh Pembelajaran Remedial Terhadap Perkembangan Kognitif Siswa Kelas IV-VI Pada Mata Pelajaran Pendidikan Agama Kristen Di Sekolah SD Inpres Tello Baru Makassar
}

\author{
Anto Muliati, Hengki Wijaya
}

\begin{abstract}
Abstrak
Pembelajaran Remedial adalah pembelajaran yang bersifat menyembuhkan, membetulkan sehingga menjadi baik atau sembuh dari masalah pembelajaran yang dirasa sulit. Melalui pembelajaran remedial siswa diharapkan mencapai Kriteria Ketuntasan Minimal (KKM) sehingga siswa dapat menyelesaikan setiap indikator yang telah dipelajari. Sedangkan, perkembangan kognitif merupakan dasar bagi kemampuan anak untuk berpikir. Perkembangan kognitif mempunyai peranan penting bagi keberhasilan anak dalam belajar karena sebagian aktivitas dalam belajar selalu berhubungan dengan masalah berpikir dalam suatu proses. Perkembangan kognitif dapat kita lihat dari KKM yang telah dicapai oleh setiap siswa.

Adapun metode yang digunakan oleh penulis dalam karya ilmiah ini adalah metode kuantitatif menggunakan populasi dan sampel. Serta pengumpulan data mengumpulkan data-data melalui wawancara dan angket. Dalam hal ini yang menjadi populasi sebanyak 68 orang dan penulis menetapkan yang menjadi sampel sebanyak 50 orang.

Adapun kesimpulan dari penelitian ini adalah pembelajaran remedial terhadap perkembangan kognitif siswa kelas IV-VI pada mata pelajan Pendidikan Agama Kristen di SD Inpes Tello Baru Makassar belum mencapai perkembangan kognitif secara maksimal, karena siswa menganggap bahwa setiap soal remedial itu kadang susah untuk dikerjakan, tetapi mereka sudah bersyukur dengan apa yang mereka sudah capai.
\end{abstract}

Kata-Kunci: Pembelajaran Remedial, Perkembangan Kognitif, Pendidikan Agama Kristen.

\section{Pendahuluan}

\section{Latar Belakang Masalah}

Kegiatan pembelajaran di sekolah dasar diharapkan dapat meningkatkan kemampuan belajar anak didik sehingga dapat memperoleh prestasi belajar yang maksimal. Akan tetapi pada kenyataannya, anak didik sebagai sasaran pendidikan di sekolah dasar senantiasa terbagi atas dua kelompok, yaitu kelompok yang berhasil atau sukses dalam belajarnya yang ditunjukkan dengan berbagai kemampuan yang dimiliki seperti cerdas atau kemampuan di atas rata-rata, dan kelompok yang mengalami masalah dalam belajarnya 
seperti membutuhkan bimbingan lebih untuk menyelesaikan suatu tugas yang telah di berikan.

Dari kedua kelompok di atas seorang guru perlu menyelenggarakan penilaian proses dan hasil belajar yang merupakan bagian dari kompetensi yang harus dikuasai oleh setiap guru. Penilaian hasil belajar hendaknya menjadi bagian integral dari proses belajar mengajar. Artinya penilaian senantiasa dilaksanakan pada setiap proses belajar mengajar sehingga pelaksanaannya berkesinambungan. ${ }^{1}$ Kualitas pembelajaran dapat dilihat dari hasil penilaiannya. Sistem penilaian yang baik akan mendorong pendidik untuk menentukan strategi mengajar yang baik dan memotivasi peserta didik untuk belajar yang lebih baik. ${ }^{2}$ Untuk melaksanakan tugas ini dengan baik seorang guru harus mempelajari peraturan perundang-undangan tentang penilaian pendidikan, salah satunya adalah Peraturan Menteri Pendidikan Nasional Nomor 19 Tahun 2007 tentang standar Pengelolaan Pendidikan Dan Peraturan Menteri Pendidikan Nasional Nomor 20 Tahun 2007 tentang Standar Penilaian Pendidikan. Fungsi penting bagi pendidik dalam mengevaluasi belajar peserta didik adalah memberikan umpan balik dalam mempertimbangkan efektifitas dan efesiensi dari proses pembelajaran yang telah dilakukan. ${ }^{3}$ Peserta didik dapat dikatakan berhasil dalam belajar jika pada diri mereka telah terjadi perubahan. Contohnya perubahan dalam aspek kemampuan berfikir misalnya perubahan dari tidak tahu menjadi tahu, atau perubahan dari tidak paham menjadi paham dan seterusnya.

Dalam proses pembelajaran setiap anak mempunyai kemampuan masing-masing. Dalam waktu yang bersamaan menerima suatu pelajaran tetapi tidak bisa menyelesaiakan suatu masalah secara bersamaan. Anak-anak ibaratkan pisau yang terbuat dari berbagai jenis logam, ada logam yang hanya perlu diasah beberapa kali kemudian bisa tajam namun ada jenis logam yang memang butuh diasah berkali-kali untuk bisa tajam. ${ }^{4}$ Maka seperti itulah gambaran anak yang lambat dalam memahami pelajaran bukannya anak tersebut tidak bisa namun anak tersebut butuh waktu yang lebih lama agar bisa memahami pelajaran.

Anak berkesulitan belajar (Learning diabilities), yaitu anak yang memiliki kesulitan belajar dalam proses psikologis dasar, sehingga menunjukkan hambatan dalam belajar berbicara, mendengarkan, menulis, membaca, dan berhitung, sedangkan mereka ini memiliki potensi kecerdasan yang baik tapi berprestasi rendah, yang bukan disebabkan oleh tunanetra, tunarungu, terbelakang mental, gangguan emosional, gangguan ekonomi, sosial, atau budaya. ${ }^{5}$ Tujuan belajar siwa tidak lain adalah untuk mengembangkan semua potensi yang ada semaksimal mungkin untuk menyalurkan kemampuannya dalam menyelesaikan suatu masalah. Dalam hal ini kesulitan belajar anak yang tidak dapat mengembangkan potensinya secara garis besarnya dibagi dalam dua bagian yaitu Faktor endogen: semua faktor yang berada di dalam diri anak tersebut, seperti ketidak mampuan atau gangguan mental, keadaan fisik, emosi tidak seimbang. Dan faktor eksogen: adalah semua faktor

\footnotetext{
${ }^{1}$ Nana Sudjana, Penilaian Hasil Proses Belajar Mengajar (Bandung: Remaja Rosdakarya,2006), 9.

${ }^{2}$ Putro Widoyoko, Evaluasi Program Pembelajaran (Yogyakarta: Pustaka Pelajar, 2001 ), 29.

${ }^{3}$ Wahidmurni dkk., Evaluasi Pembelajaran Kompetensi dan Praktik (Yogyakarta: Nuha Litera, 2010), 13,14 .

${ }^{4}$ Ali Ridho, Mengatasi Anak yang Lambat dalam Memahami Pelajaran (Bandung: Pustaka Pelajar, 1997), 134.

${ }^{5}$ Mohamad Syarif Sumantri, Stategi Pembelajaran Teori dan Praktik di Tingkat Pendidikan Dasar (Jakarta: RajaGrafindo Persada, 2016), 168.
} 
yang berada di luar diri anak, misalnya orang tua, guru, dan lingkungan sekitarnya jadi semua hal diluar diri si anak. ${ }^{6}$

Dari masalah di atas penulis berpendapat bahwa untuk membantu anak yang lambat dalam belajarnya atau anak yang mempunyai kesulitan dalam belajar maka seorang guru perlu mengadakan remedial untuk membimbing anak tersebut menjadi memahami apa yang sebelumnya belum ia pahami khususnya dalam pelajaran yang telah ia terima.

Pembelajaran remedial merupakan tindak lanjut guru terhadap proses dan hasil belajar peserta didik. Program remedial adalah program pembelajaran yang diberikan kepada peserta didik yang belum mencapai kompetensi minimalnya dalam satu kompetensi dasar tertentu. Metode yang digunakan dapat berfariasi sesuai dengan sifat, jenis, dan latar belakang kesulitan belajar yang dialami peserta didik dan tujuan pembelajarannya pun dirumuskan sesuai dengan kesulitan yang dialami peserta didik. Pada program pembelajaran remedial, media belajar harus betul-betul disiapkan guru agar dapat mempermudah peserta didik dalam memahami pelajaran yang dirasa sulit. ${ }^{7}$ Identifikasi kasus dan faktor- faktor yang mempengaruhi timbulnya kesulitan belajar tidak akan bermanfaat apabila tidak diikuti dengan tindakan-tindakan yang dapat membantu para siswa yang mengalami kesulitan belajar.

Di samping itu, guru perlu mempertimbangkan apakah pengajaran remedial yang direncanakan itu akan diberikan kepada masing-masing siswa secara individual atau kepada kelompok-kelomok siswa. Perencanaan seperti ini juga meliputi pertimbangan tentang waktu dan tempat pelaksanaan pengajaran remedial. Pengajaran remedial hendaknya diakhiri dengan tes untuk mengetahui sampai berapa jauh usaha yang telah direncanakan dan dilaksanakan dapat membantu siswa. ${ }^{8}$ Tujuan pembelajaran remedial adalah guru akan membantu peserta didik, untuk memahami kesulitan dalam belajar yang dihadapi peserta didik, untuk memperbaiki cara belajar dan sikap belajar yang dapat mendorong tercapainya hasil belajar yang optimal. Khususnya dalam bidang ranah kognitif.

Ranah kognitif adalah ranah yang mencakup kegiatan mental (otak). Segala upaya yang menyangkut aktifitas otak adalah termasuk dalam ranah kognitif. Dalam ranah kognitif itu terdapat enam jenjang proses berfikir, mulai dari jenjang terendah sampai dengan jenjang yang paling tinggi. Keenam jenjang yang dimaksud adalah: (1).

Pengetahuan/hafalan/ingatan (knowledge), (2) pemahaman (comprehension), (3) Penerapan (application), (4) Analisis (analysis), (5) sintesis (synthesis) dan (6) Penilaiaan (evaluation). ${ }^{9}$

Tujuan kognitif berorientasi kepada kemampuan "berfikir", mencakup kemampuan intelektual yang lebih sederhana, yaitu mengingat, sampai pada kemampuan memecahkan masalah yang menuntut siswa untuk menghubungkan dan menggabungkan gagasan, metode atau prosedur yang sebelumnya dipelajari untuk memecahkan masalah tersebut.

${ }^{6}$ Singgih D. Gunarsa dan Yulia Singgih D. Gunarsa, Psikologi Perkembangan Anak Dan Remaja (Jakarta: BPK Gunung Mulia, 1991), 126-127.

${ }^{7}$ Mohamad Syarif Sumantri, Strategi Pembelajaran Teori dan Praktik di Tingkat Pendidikan Dasar (Jakarta: RajaGrafindo Persada, 2016), 422.

${ }^{8}$ Amrin, "Diaknosis Kesulitan Belajar dan Pengajaran Remedial dalam Pendidikan IPA," Jurnal Pendidikan Fisika, 3 No.01 (Juli 2013): 34. Diakses 18 Maret, 2018. http://journal.unismuh.ac.id/index.php/jpf/article/view/185/172,

${ }^{9}$ Anas Sudijono, Pengantar Evaluasi Pendidikan (Jakarta: RajaGrafindo Persada, 2006), 49-50. 
Sehingga dapat disimpulkan bahwa kawasan kognitif adalah subtaksonomi yang mengungkapkan tentang kegiatan mental yang sering berawal dari tingkat "mengingat" sampai ketingkat yang paling tinggi yaitu" mencipta. ${ }^{10}$ Mengukur keberhasilan siswa yang berdimensi kognitif (ranah cipta) dapat dilakukan dengan berbagai cara, baik dengan tes tertulis maupun dengan tes lisan dan perbuatan. ${ }^{11}$

Sehubugan dengan itu pendidikan agama Kristen disekolah hendaknya mencapai target yang telah ditetapkan melalui proses pembelajaran yang efektif melalui proses pembelajaran remedial untuk menolong siswa yang lambat dalam belajarnya untuk mengembangkan pengetahuan atau ranah kognitifnya secara optimal. Sehingga semua pelajaran agama yang telah diterima oleh setiap siswa, seharusnya dapat dimengerti secara jelas bahkan dapat dipraktikkan dalam kehidupan masing-masing. Tujuan pendidikan agama Kristen ialah menghasilkan perubahan dalam diri orang yang dididik. Tidak hanya sekedar mendengar, memahami tetapi bagaimana seorang siswa dapat mengaplikasikan apa yang telah ia terima. Pendidikan Kristen yang dituntut oleh Tuhan Yesus adalah pendidikan yang mencapai tujuan akhir: "Ajarlah mereka melakukan segala sesuatu yang telah Kuperintahkan kepadamu," kata-Nya (Mat. 28:20). ${ }^{12}$

Pendidikan agama Kristen hendaknya menjadi cerminan bagi setiap siswa dimanapun mereka berada, baik disekolah maupun dilingkungan sosialnya. Menjadi cerminan Kristus seharusnya membawa dampak yang baik kepada setiap orang yang dijumpainya, untuk itu selain dalam Keluarga dan lembaga Gereja pendidikan agama Kristen disekolah pun begitu sangat berperan penting dalam kehidupan setiap siswa. Bukan hanya sekedar belajar tetapi memberi kepastian bahwa pelajaran yang telah diterima dapat dipahami dan dapat dipraktekkan.

\section{Pokok Masalah}

Berdasarkan latar belakang masalah diatas, maka pokok masalah dalam penulisan karya ilmiah ini adalah sejauhmana pengaruh remedial terhadap perkembangan kognitif siswa kelas IV-VI terhadap pelajaran Pendidikan Agama Kristen di SD Inpres Tello Baru Makassar.

\section{Tujuan Penelitian}

Berdasarkan pokok masalah diatas, maka dapat dijelaskan bahwa adapun tujuan yang hendak dicapai dalam penelitian ini adalah untuk melihat sejauhmana pengaruh remedial terhadap pekembangan kognitif siswa kelas IV-VI terhadap pelajaran pendidikan agama Kristen di SD. Inp. Tello baru Makassar.

\section{Manfaat Penelitian}

Adapun manfaat dari penelitian dan penulisan karya ilmiah ini adalah :

\footnotetext{
${ }^{10}$ Martinis Yamin, Desain Baru Pembelajaran Konstruktivistik (Jambi: Referensi, 2012), 41.

${ }^{11}$ Abdur Rohman, "Pengaruh Bentuk Tes Pilihan Ganda Dan Jawaban Singkat Terhadap Kemampuan Kognitif Siswa Di Tinjau Dari Jenis Kelamin pada Sub Pokok Bahasan Kubus Dan Balok (Study Eksprimen di kelas VIII SMP Negeri 1 Ciledug)" (Skripsi S.Pd., Institut Agama Islam Negeri (IAIN) Syekh Nurjati Cirebon, 2013), diakses 18 Maret 2018. http://repository.syekhnurjati.ac.id/1412/1/ABDUR\%20ROHMAN_OK.pdf

${ }^{12}$ Leatha Humes, Arah Pendidikan Kristen (Malang: PPII,1982), 41.
} 
Pertama, untuk mengetahui manfaat pengaruh remedial terhadap perkembangan kognitif siswa kelas IV-VI terhadap pelajaran pendidikan agama Kristen di SD Tello Baru Makassar.

Kedua, untuk mengetahui beberapa model strategi dan teknik pendekatan pengajaran remedial yang berpengaruh pada perkembangan kognitif siswa.

Ketiga, sebagai bahan acuan bagi seorang guru yang akan mengadakan program remedial.

Keempat, sebagai salah satu syarat untuk menyelesaikan Strata Satu (S1) pada program pendidikan.

\section{Metode Penelitian}

Adapun metode penelitian yang penulis gunakan adalah studi kasus dengan metode penelitian kuantitatif dengan tehnik pengumpulan data sebagai berikut:

Pertama, studi kepustakaan yaitu penulis mengambil data menggunakan data primer dan data sekunder dari buku-buku dan journal yang berhubungan dengan materi pengaruh remedial terhadap perkembangan kognitif siswa kelas IV-VI terhadap pelajaran pendidikan agama Kristen.

Kedua, melakukan wawancara terhadap seorang guru yang menggunakan metode remedial dalam perkembangan kognitif siswa, terhadap pelajaran pendidikan agama Kristen.

Ketiga, membuat kuesioner (daftar pertanyaan) untuk mengetahui bagaimana upaya guru dalam mengadakan program remedial dalam perkembangan kognitif siswa terhadap pelajaran pendidikan agama Kristen kelas IV-VI di SD. Tello Baru Makassar.

\section{Batasan Penulisan}

Untuk mendapatkan data yang akurat dari penelitian karya ilmiah ini, maka penulis memberikan batasan penulisan yaitu pengaruh remedial terhadap pekembangan kognitif siswa kelas IV-VI terhadap pelajaran pendidikan agama Kristen di SD. Inp. Tello baru Makassar.

\section{Kesimpulan}

Dari analisis di atas maka penulis dapat menyimpulkan bahwa:

Pertama, siswa sering mengikuti pembelajaran remedial yang dilaksanakan pada mata pelajaran agama. Pada indikator yang tidak mencapai KKM maka akan mengikuti remedial hingga nilai yang diperoleh tuntas. Walaupun Setelah mengikuti pembelajaran remedial siswa jarang mengalami peningkatan nilai seperti hasil angket yang diberikan kepada siswa untuk mendapatkan informasi nilai. Pemberian tugas remedial yang dikerjakan termasuk sering mudah untuk diselesaikan. Tetapi setelah mengikuti pembelajaran remedial siswa lebih rajin untuk mengerjakan latihan soal.

Siswa selalu merasa nyaman dengan suasana ruangan kelas saat mengerjakan tugas yang diberikan oleh guru. Dan siswa selalu menghafalkan ayat hafalan yang diberikan oleh guru mereka.

Kedua, pada tingkat perkembangan kognitif anak. Siswa selalu bertanya pada guru jika ada hal yang tidak siswa pahami. Ini dapat dilihat bahwa setiap anak yang mengikuti remedial telah mencapai batas KKM dan telah dinyatakan tuntas. Diambil dari hasil angket siswa mengatakan bahwa mereka belajar karena kemauan diri sendiri bukan paksaan dari 
guru, orang tua, maupun teman. Siswa juga selalu membantu teman untuk menyelesaikan tugas di sekolah. Siswa juga selalu segera menjawab saat ketika diberi pertanyaan. Dan siswa juga selalu mempunyai jadwal belajar setiap hari di rumah.

Ketiga dari setiap indikator yang tidak mencapai batas KKM maka akan dituntaskan pada indikator yang bersangkutan dengan tingkat kesukaran soal yang berbeda-beda. Dalam periaku siswa saat mengikuti pelajaran mereka selalu berdoa sebelum mengikuti pelajaran agama. Dan siswa

selalu puas dengan prestasi yang mereka dapatkan meski tidak sepenuhnya mendapatkan nilai yang sempurnah atau dengan kata lain mereka hanya mendapatkan nilai standar KKM (75) walaupun nilai hasil remedial mereka 90.

\section{Kepustakaan}

Amrin. "Diaknosis Kesulitan Belajar dan Pengajaran Remedial dalam pendidikan IPA," Jurnal Pendidikan Fisika 03, No.01 (Juli2013): 1- 150. Diakses 18 Maret 2018. http://journal.unismuh.ac.id/index.php/jpf/article/view/185/172.

Arifin, Zainal. Evaluasi Pembelajaran Prinsip Teknik, dan Prosedur. Bandung: Remaja Rosdakarya,2016.

Depniknas. Pembelajaran Remedial. Jakarta: Direktorat Pembina Sekolah Menengah Atas, 2008.

Dosen-dosen STT-HKBP dan FKIP Nommensen. Pendidikan Agama Kristen. Yogyakarta: Taman Pustaka Kristen, 1994.

Gunarsa, Singgih. D, Yulia Singgi D. Gunarsa. Psikologi Perkembangan Anak dan Remaja. Jakarta: BPK Gunung Mulia, 1991.

Gunarsa, Singgih D. Dasar Dan Teori Perkembangan Anak. Jakarta: BPK Gunung Mulia, 2006.

Gunarsa, YuliaSinggih D. Asas-asas Psikologi Keluarga Idaman. Jakarta: BPK Gunung Mulia, 2000.

Humes, L. Arah Pendidikan Kristen. Malang: PPII, 1982.

Homrighausen, E. G. dan I.H. Enklaar Pendidikan Agama Kristen. Jakarta: BPK Gunung Mulia, 2005.

Hasis, I. Surawan, Gea Candra. Remedial Teaching. Malang: Universitas Negeri Malang Press, 2001.

Kusrahmadi, Sigit Dwi. "Sumbangan Pendidikan Agama Kristen dalam Mewujudkan Watak Bangsa."Jurnal Dinamika 02, No.01 (2013): 1-180. Diakses 21 April 2018. http://jurnalnasional.ump.ac.id/index.php/dinamika/article/view/938/875. 
Kusmitasari, Reni "Persepsi Mahasiswa Pada Sistym Layanan Sirkulasi UPT Perpustakaan Universitas Halu Oleo.” Jurnal Ilmu Komunikasi UHO 1, no. 3 (Maret 2016) Diakses 12 Juni 2018. http://ojs.uho.ac.id/index.php/KOMUNIKASI/article/dowload/1637/1192.

Makmun, AbinS. Psikologi Kependidikan. Bandung: Remaja Rosdakarya, 2007.

Nuhamara, Daniel. Pembimbing PAK. Bandung: Jurnal Info Media, 2007.

Nasir, Mohammad. Metode Penelitian. Jakarta: Ghalia Indonesia, 1998.

Nuhamara, Daniel. "Pengutamaan Dimensi Karakter Dalam Pendidikan Agama Kristen" Jurnal Jaffray [Online], Volume 16 Nomor 1 (19 Maret 2018)

Purwanto, N. Surawan, Gea Chandra. Prinsip-Prinsip Dan Teknik Evaluasi Pengajaran. Bandung: Remaja Rosdakarya, 2008.

Ridho, Ali. Mengatasi Anak yang Lambat dalam Memahami Pelajaran. Bandung: Pustaka Pelajar, 1997.

Sudjana, Nana. Penilaian Hasil Proses Belajar Mengajar. Bandung: Remaja Rosdakarya, 2006.

Sumantri, Mohamad Syarif. Stategi Pembelajaran Teoridan Praktik di Tingkat Pendidikan Dasar. Jakarta: RajaGrafindo Persada, 2016.

Sudijono, Anas. Pengantar Evaluasi Pendidikan. Jakarta: Raja Grafindo Persada, 2006.

Syah, Muhibbin. Psikologi Pedidikan Dengan Pendekatan Baru. Bandung: Remaja Rosdakarya, 2000.

Syamsudin, A. Surawan, Gea Candra. Psikologi Kependidikan. Bandung: Remaja Rosdakarya,2004.

Simamora, Dame Taruli, Gultom Rida. Pendidikan Agama Kristen Kepada Remaja dan Pemuda. Medan: MITRA, 2011.

Setiawani, Mary Go. Menerobos Dunia Anak. Bandung: Kalam Hidup, 2000.

Subagyo, Andreas B. Pengantar Riset Kualitatif. Bandung: Kalam Hidup, 2004.

Sugiyono. Metode Penelitian Kuantitatif, Kualitatif dan Konotasi (mixed Methods) Bandung: Alfabeta, 2012.

Tung, Khoe Yao. Filsafat Pendidikan Kristen. Yogyakarta: ANDI, 2013.

Uno, Hamzah B. Orientasi Baru Dalam Psikologi Pembelajaran. Jakarta: Bumi Aksara, 2006.

Widoyoko, Putro. Evaluasi Program Pembelajaran. Yogyakarta: Pustaka Pelajar, 2001.

Wahidmurni, Ali ridho, Muhibbinsyah, Evaluasi Pembelajaran Kompetensi dan Praktik. Yogyakarta: Nuha Litera, 2010. 
Yamin, Martinis. Desain Baru Pembelajaran Konstruktivistik. Jambi: Referensi, 2012.

Wadi, Elsyana, DAN Selfina, Elisabet. "Peran Orang Tua Sebagai Keluarga Cyber Smart Dalam Mengajarkan Pendidikan Kristen Pada Remaja GKII Ebenhaezer Sentani Jayapura Papua" Jurnal Jaffray [Online], Volume 14 Nomor 1 (14 Maret 2016).

Winkel, W.S. Psikologi Pengajaran. Jakarta: Gramedia, 1987.

Wijaya, Hengki (ed.). Metodologi Penelitian Pendidikan Teologi. Makassar: Sekolah Tinggi Theologia Jaffray, 2016. 